\title{
Tallgrass prairie vegetation response to spring burning dates, fertilizer, and atrazine
}

\author{
ROBERT B. MITCHELL, ROBERT A. MASTERS, STEVEN S. WALLER, KENNETH J. \\ MOORE, AND LINDA J. YOUNG
}

\begin{abstract}
Authors are assistant professor, Dep. Range, Wildl. and Fisheries Manage., Texas Tech Univ., Lubbock, Tex. 79409, rangeland scientist, USDA-ARS, associate dean, College of Agricultural Sciences and Natural Resources, Univ. Nebraska, Lincoln, Neb. 68583, professor, Dep. Agronomy, Iowa State Univ., Ames, Iowa 50011, and associate professor, Dep. Biometry, Univ. Nebraska, Lincoln, Neb. 68583.
\end{abstract}

\begin{abstract}
Tallgrass prairies provide an important source of hay and summer forage in eastern Nebraska. A study was conducted in 1989 and 1990 on 2 late seral tallgrass prairies near Lincoln and Virginia, Nebraska to determine if production of selected components of tallgrass prairie communities could be altered by burning (not burned, or burned in either early, mid-, or late spring) and applying fertilizer ( 0 and $67-23 \mathrm{~kg} \mathrm{~N}-\mathrm{P} \mathrm{ha}{ }^{-1}$ ) and atrazine [6chloro-N-ethyl-N'-(1-methylethyl)-1,3,5-triazine-2,4-diamine] (0 and $2.2 \mathrm{~kg}$ a.i. ha $\left.{ }^{-1}\right)$. Vegetation was harvested the year treatments were applied at about 30-day intervals starting in June and ending in August. Maximum big bluestem (Andropogon gerardii var. gerardii Vitman) accumulated standing crop (ASC) on unburned areas and areas burned in mid-spring occurred later in 1990 than in 1989. Burning in late spring 1989 maintained big bluestem ASC above $1,100 \mathrm{~kg} \mathrm{ha}^{-1}$ through July, whereas big bluestem ASC declined below $840 \mathrm{~kg} \mathrm{ha}^{-1}$ in July on areas where other burn treatments were applied. In 1990, big bluestem ASC exceeded $1,570 \mathrm{~kg} \mathrm{ha}^{-1}$ in June on areas burned in early and midspring and exceeded $1,500 \mathrm{~kg} \mathrm{ha}^{-1}$ in July on areas that were not burned or burned in mid- or late spring. From July to August 1990 big bluestem ASC declined below $730 \mathrm{~kg} \mathrm{ha}^{-1}$ for all treatments except the late spring burn treatment where ASC was $1,340 \mathrm{~kg} \mathrm{ha}^{-1}$. Burning in late spring reduced prairie dropseed [Sporobolus heterolepis (A. Gray) A. Gray] and tall dropseed [S. asper (Michx.) Kunth.] ASC by at least 67\% in June 1990 compared to areas burned in early and mid-spring. Cool-season grass ASC at Virginia declined $86 \%$ in June when burned in late spring compared to areas that were not burned. Fertilization increased big bluestem ASC by about 23 and 29\% in June and July. Vegetation response to atrazine was variable. Atrazine had a negligible effect on big bluestem ASC. Burning late seral tallgrass prairie in late spring increased big bluestem ASC later in the growing season and decreased cool-season grasses more effectively than burning earlier in the spring.
\end{abstract}

The authors wish to thank Kevin Grams, Mark Dragastin, and Pat Speirs for their assistance. We thank the Animal Science Dep., Univ. Nebraka, and NineMile Prairie Committee for permission to conduct these studies at the DalbeyHalleck Farm and Nine-Mile Prairie, respectively. Mention of a trade name in this paper does not constitute a recommendation by the Univ. Nebraska or the USDAARS nor does it imply registration under FIFRA. Contribution Number 10812 of the Agricultural Research Division, Univ. Nebraska-Lincoln, and the USDA-ARS.

Manuscript accepted 21 May 1995.
Key Words: prescribed fire, nitrogen, warm-season grasses, Andropogon gerardii, Sorghastrum nutans, cool-season grasses, sedges.

Introduced cool-season forages and crop residues provide abundant spring and fall grazing for livestock enterprises in the central Great Plains. A need exists for high quality perennial forages during the summer (Krueger and Curtis 1979). This imbalance in seasonal forage supply limits the production potential of livestock operations. Warm-season grasses of properly managed tallgrass prairies can fill this gap in summer forage availability. Common warm-season grasses in tallgrass prairies include big bluestem (Andropogon gerardii var. gerardii Vitman), indiangrass [Sorghastrum nutans (L.) Nash], switchgrass (Panicum virgatum L.), little bluestem [Schizachyrium scoparium (Michx.) Nash], and sideoats grama [Bouteloua curtipendula (Michx.) Torr.]. In the central Great Plains, overgrazing has caused a shift in species composition from warm-season grasses to introduced cool-season grasses, Kentucky bluegrass (Poa pratensis L.) and smooth bromegrass (Bromus inermis Leyss.) (Waller and Schmidt 1983), and to a lesser extent undesirable warm-season grasses, prairie dropseed [Sporobolus heterolepis (A. Gray) A. Gray] and tall dropseed [S. asper (Michx.) Kunth.].

Fire and application of fertilizer and atrazine [6-chloro-N-ethyl$\mathrm{N}^{\prime}$-(1-methylethyl)-1,3,5-triazine-2,4-diamine] can improve or maintain warm-season grass dominance in tallgrass prairies (Gillen et al. 1987, Masters et al. 1992). The response of tallgrass prairie vegetation to these treatments is influenced by factors including successional status (Gillen et al. 1987), date of burning (Anderson 1965, Towne and Owensby 1984), and date of fertilizer application (Rehm et al. 1976). Fire and fertilizer application have increased warm-season grass yields in Oklahoma (Graves and McMurphy 1969), Kansas (Owensby and Smith 1979), and Nebraska (Masters et al. 1992; Mitchell et al. 1994). Atrazine has been used to selectively control Kentucky bluegrass and smooth bromegrass in established warm-season grass stands (Samson and Moser 1982, Waller and Schmidt 1983). Engle et al. (1990) determined that atrazine suppressed prairie threeawn in tallgrass prairies. They also found that combining burning with atrazine treatment did not improve prairie threeawn control and burning within 1 month before atrazine application decreased threeawn control. Atrazine applied 6 months after burning in late summer 
did not increase grass standing crop in Oklahoma tallgrass prairies (Engle et al. 1993).

There is a lack of information on the influence of spring burning date or the combined effect of spring burning date, fertilizer, and atrazine on the yield of tallgrass prairie vegetation during the summer growing season. The objective of this study was to determine the effects of burning on different dates in the spring coupled with fertilizer and atrazine application on seasonal yield distribution of various vegetation components in late seral tallgrass prairies.

\section{Materials and Methods}

This study was conducted in 1989 and 1990 on late seral tallgrass prairies near Lincoln, Nebr. (Nine-Mile Prairie, University of Nebraska Foundation) and Virginia, Nebr. (Dalbey-Halleck Farm, University of Nebraska). Soils at Lincoln and Virginia were Shelby clay loam (Typic Argiudoll) and Pawnee clay loam (Aquic Arguidoll), respectively. The site near Lincoln had not been grazed since 1968 and had been burned in mid- to late April at $3 \mathrm{yr}$ intervals. The site was also burned by a wildfire on 10 March 1988. The site near Virginia had been grazed during the summer each year since 1961. Livestock were excluded from the areas used for this study in 1989 and 1990 . Since the early 1970's, musk thistle (Carduus nutans L.) has been controlled at or adjacent to each site by annual applications of 2,4-D [(2,4dichloro-phenoxy) acetic acid] and dicamba (3,6-dichloro-oanisic acid).

Big bluestem was the dominant species at both sites (Table 1).

Table 1. Botanical composition of tallgrass prairies near Lincoln and Virginia, Nebraska'.

\begin{tabular}{lccccc}
\hline \hline \multirow{2}{*}{$\begin{array}{l}\text { ppecies or } \\
\text { category }\end{array}$} & \multicolumn{2}{c}{1989} & & \multicolumn{2}{c}{1990} \\
\cline { 2 - 3 } \cline { 5 - 6 } & Lincoln & Virginia & & Lincoln & Virginia \\
\hline Big bluestem & 60 & 42 & 62 & 47 \\
Indiangrass & 16 & 14 & & 14 & 15 \\
$\begin{array}{l}\text { Prairie \& tall } \\
\text { dropseed }\end{array}$ & 1 & 11 & & 0 & 4 \\
Other warm- & & & & \\
$\quad$ season grasses & 4 & 6 & 18 & 16 \\
Cool season & 3 & 22 & 1 & 16 \\
grasses & & & & \\
Sedges & 6 & 4 & & 1 & 2 \\
Forbs & 10 & 1 & 4 & 0 \\
\hline
\end{tabular}

${ }^{T}$ Expressed as a percent of total herbaceous vegetation standing crop harvested from plots in mid-July of the year indicated. Plots harvested had not been treated with fire fertilizer, or atrazine.

Switchgrass, indiangrass, little bluestem, and sideoats grama were common at both sites. Prairie dropseed and tall dropseed were common only at Virginia. Kentucky bluegrass, smooth bromegrass, Scribner panicum [Dichanthelium oligosanthes (Schult.) Gould var. scribnerianum Nash], and Wilcox panicum [Dichanthelium oligosanthes (Schult.) Gould var. wilcoxianum (Vasey) Gould and Clark] were common cool-season grasses at both sites.

The experiment was designed as a randomized complete block arranged as a split plot with a $2 \times 2$ factorial arrangement of subplot treatments and 3 replications per treatment combination. The
4 whole plots $(12 \times 20-\mathrm{m})$ in each replication were either not burned or burned with a headfire on 1 of 3 dates in the spring (Table 2). Litter and standing dead biomass were left undisturbed on areas that were not burned. Early burns were conducted approximately 3 weeks before warm-season grass emergence, mid-spring burns at big bluestem emergence, and late burns when big bluestem was at the $\mathrm{V}_{2}$ ( 2 collared leaves) mean growth stage (Moore et al. 1991). Fertilizer (0 and 67-23 kg N-P ha ${ }^{-1}$ ) and atrazine $\left(0\right.$ and $2.2 \mathrm{~kg}$ a.i. ha $\left.{ }^{-1}\right)$ were randomly applied to subplots $(6 \times 10-\mathrm{m})$ in all possible combinations within each whole plot at each site in 1989 . The study was repeated in 1990 at each site on areas that had not been grazed or treated in 1989. Fertilizer was applied in May with a Gandy fertilizer spreader as ammonium nitrate (34-0-0) and triple superphosphate (0-46-0). A $90 \%$ wettable powder atrazine formulation was applied in solution at a delivery rate of 190 liters ha ${ }^{-1}$ in April 1989 and 1990 with a tractor-mounted, air-pressurized sprayer (Table 2).

Table 2. Date of burn, fertilizer, and atrazine treatments at tallgrass prairies near Lincoln and Virginia, Nebr. in 1989 and 1990.

\begin{tabular}{|c|c|c|c|c|}
\hline \multirow{2}{*}{$\begin{array}{l}\text { Spring } \\
\text { treatment }\end{array}$} & \multicolumn{2}{|c|}{ Lincoln } & \multicolumn{2}{|c|}{ Virginia } \\
\hline & 1989 & 1990 & 1989 & 1990 \\
\hline Early bum & 31 March & 2 April & 5 April & 27 March \\
\hline Mid burn & 19 April & 27 April & 20 April & 24 April \\
\hline Late burn & 15 May & 14 May & 16 May & 17 May \\
\hline $\begin{array}{l}\text { Fertilizer } \\
\text { Atrazine }\end{array}$ & $\begin{array}{l}19 \text { May } \\
26 \text { April }\end{array}$ & $\begin{array}{l}\text { 18 May } \\
16 \text { April }\end{array}$ & $\begin{array}{l}17 \text { May } \\
25 \text { April }\end{array}$ & $\begin{array}{l}18 \mathrm{May} \\
12 \mathrm{April}\end{array}$ \\
\hline
\end{tabular}

${ }^{1}$ Fertilizer applied at rates of 0 and $67-23 \mathrm{~kg} \mathrm{~N}-\mathrm{P} \mathrm{ha}{ }^{-1}$ and atrazine at rates of 0 and 2.2 kg a.i. ha ${ }^{-1}$.

Immediately prior to application of each burn treatment, fine fuel loads were determined by clipping all herbage to a $2-\mathrm{cm}$ stubble height within a $0.25-\mathrm{m}^{2}$ quadrat randomly located within each whole plot. Herbage within each quadrat was separated into live and dead components, oven-dried at $60^{\circ} \mathrm{C}$, and weighed. At Lincoln, the fine fuel load averaged $4,700 \mathrm{~kg} \mathrm{ha}^{-1}$ and was comprised of 0,2 , and $15 \%$ live plant tissue at time of early, mid-, and late spring burn dates, respectively. At Virginia, the fine fuel load averaged $4,000 \mathrm{~kg} \mathrm{ha}^{-1}$ and was comprised of 0,9 , and $28 \%$ live plant tissue at time of the early, mid-, and late spring burn dates, respectively.

Herbage was sampled 3 times from each site at about 30-day intervals beginning in mid-June and ending in August the year of treatment application. Vegetation was harvested within two, 0.25$\mathrm{m}^{2}$ quadrats located within each subplot. Vegetation within each quadrat was clipped to a $2-\mathrm{cm}$ stubble height, separated into selected categories, oven dried at $60^{\circ} \mathrm{C}$, and weighed to determine dry matter production. Areas disturbed by previous sampling activity were avoided during quadrat placement. Vegetation was separated into the following categories: big bluestem; indiangrass, dropseeds (prairie and tall); other warm-season grasses (little bluestem; switchgrass, and sidegoats grama); cool-season grasses; sedges; forbs; and dead vegetation.

Accumulated standing crop (ASC) was calculated to characterize vegetation productivity throughout the summer. June ASC was produced between growth initiation or burning and the June harvest. July ASC was produced between the June and July harvests. August ASC was produced between the July and August harvests.

Data were analyzed using the general linear model procedure 
(SAS 1985). Sources of variation were year, site, harvest date, burn treatment, fertilizer, and atrazine. Harvest dates were treated as repeated-measures in time and analyzed using a split-plot design described by Steel and Torrie (1980). Results from analysis of variance were used to determine the response of prairie vegetation accumulated standing crop to treatments over time. Treatment means of significant $(\mathrm{P} \leq 0.05)$ main effects and interactions were compared using Fisher's-protected least significant difference test at $\propto=0.05$ (Steel and Torrie 1980).

\section{Results and Discussion}

Total annual precipitation was less than the 50 -yr average at both sites in 1988, 1989, and 1990. Precipitation in 1989 and 1990 was 12 and $2 \%$ below normal at Lincoln, and 30 and $16 \%$ below the long-term average at Virginia, respectively (Fig. Ia and b). Seasonal distribution of precipitation differed between 1989 and 1990 at both sites. In 1989, precipitation was well below the long-term average for the entire growing season at Lincoln and Virginia. In contrast, precipitation was close to or exceeded the long-term average through the growing season in 1990 .

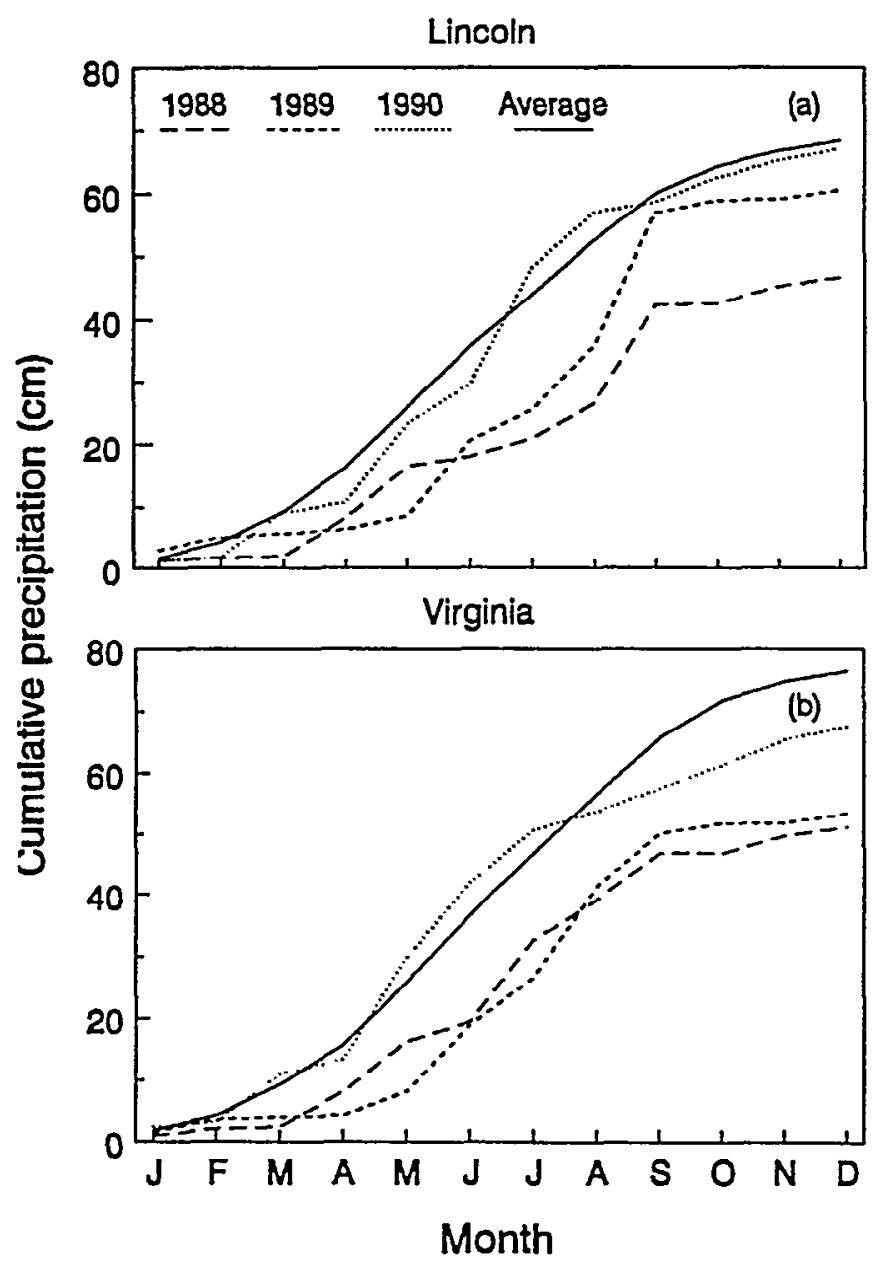

Fig. 1. Cumulative precipitation at (a) Lincoln and (b) Virginia, Nebr. during 1988, 1989, 1990, and the 50-yr average.

\section{Warm-Season Grasses}

Big bluestem accumulated standing crop (ASC) was primarily influenced by date of burning and fertilization. The harvest date by burning date by year interaction and harvest date by fertilization interaction were significant $(P \leq 0.05)$, but interactions that included atrazine were not significant $(P \geq 0.20)$. Date of greatest big bluestem ASC varied by year and date of burning (Fig. 2a). Big bluestem ASC in June 1989 did not differ significantly among burn treatments. In contrast, big bluestem ASC in July 1989 was greatest on areas burned earlier in late spring and was at least $40 \%$ greater than areas burned in the spring. In August 1989, big bluestem ASC became negative for each burn treatment. These negative values occurred because the rate of growth slowed to the point where herbage disappearance exceeded herbage accumulation.

Maximum big bluestem accumulated standing crop (ASC) for nonburned and mid-spring burned areas occurred later in 1990 than in 1989 (Fig. 2a). Accumulated standing crop on nonburned areas and those burned in mid- and late spring exceeded ASC on areas burned in early spring by about 50\% in July 1990. By August 1990, big bluestem ASC on areas burned in late spring was at least $46 \%$ greater than ASC on other areas (Fig. 2a).

Time of maximum big bluestem accumulated standing crop (ASC) varied by year, but was successfully manipulated by altering date of burning in the spring. Burning in late spring 1989 maintained big bluestem ASC above $1,100 \mathrm{~kg} \mathrm{ha}^{-1}$ through July, whereas big bluestem ASC declined to less than $840 \mathrm{~kg} \mathrm{ha}^{-1}$ in July on areas where other burn treatments were applied (Fig. 2a). In 1990 , big bluestem ASC exceeded $1,570 \mathrm{~kg} \mathrm{ha}^{-1}$ in June on areas burned in early and mid-spring and exceeded $1,500 \mathrm{~kg} \mathrm{ha}^{-1}$ in July on areas that were not burned or burned in mid- or late spring. From July to August 1990 big bluestem ASC declined below $730 \mathrm{~kg} \mathrm{ha}^{-1}$ for all treatments except the late spring burn treatment where ASC was $1,340 \mathrm{~kg} \mathrm{ha}^{-1}$. The difference in distribution of growth in 1989 and 1990 may be explained by the lower than average precipitation at Lincoln and Virginia in 1989 as compared to precipitation that was close to the average through much of the spring and summer of 1990 . Increased precipitation in 1990 likely sustained big bluestem growth later into the summer than during 1989 when less precipitation was received.

Burning in late spring consistently shifted maximum big bluestem accumulted standing crop (ASC) later into the summer than the other treatments (Fig. 2a). Although soil water content was not measured during the growing season, delaying burning until late spring may have conserved soil water for use by big bluestem later in the growing season. The plant litter that remained on the site until burning in late spring likely protected the soil surface from desiccating winds, solar insolation, and damage to soil aggregation by raindrop impact (Anderson 1965). Another reason for the shift in big bluestem production could have been interruption and delay of tiller development caused by burning in late spring.

The positive response of big bluestem to burning has been observed by others. Burning substantially increased big bluestem production in Illinois (Old 1969), Kansas (Knapp 1985), Missouri (Kucera and Ehrenreich 1962), Nebraska (Masters et al. 1992), Oklahoma (Svejcar and Browning 1988), and Wisconsin (Peet et al. 1975). Svejcar (1990) indicated that species composition and timing of fire strongly influences the response of tallgrass prairie vegetation. Generally, burning in late spring benefits big bluestem, while adversely affecting grasses and forbs that emerge earlier in the spring than big bluestem. 
Big bluestem
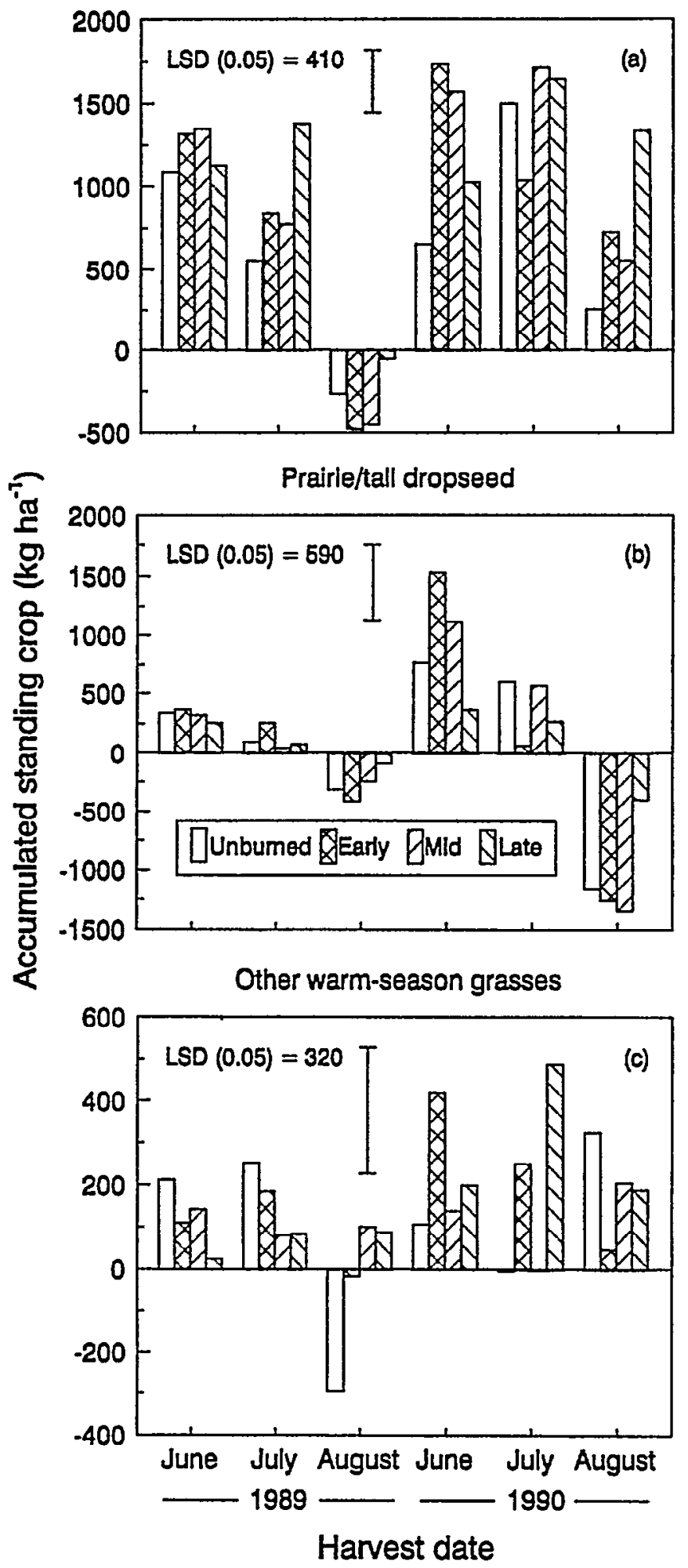

Fig. 2. Accumulated standing crop of (a) big bluestem, (b) prairie and tall dropseed, and (c) other warm-season grasses harvested in June, July, and August following spring burning on 3 dates at tallgrass prairies near Lincoln and Virginia, Nebr. in 1989 and 1990. Values are averaged across sites and fertilizer and atrazine treatments.
Fertilization increased $(\mathrm{P}<0.01)$ big bluestem biomass in June and July, but had little effect in August. When compared to nonfertilized areas, fertilizer increased big bluestem accumulated standing crop (ASC) 23 and $29 \%$ in June and July, respectively. These results are consistent with studies in Oklahoma (Graves and McMurphy 1969) and Kansas (Moser and Anderson 1965) tallgrass prairies where increases in forage production were observed following $\mathrm{N}$ fertilization.

Prairie dropseed and tall dropseed comprised very little of the total vegetation at the Lincoln site, but accounted for as much as $11 \%$ of that at the Virginia site (Table 1). Accumulated standing crop of the dropseeds in June was reduced $(P=0.03)$ to $370 \mathrm{~kg} \mathrm{ha}^{-1}$ by late spring burning when compared to areas burned in early and mid-spring 1990 at Virginia (Fig. 2b). The caespitose growth characteristics of prairie dropseed, the dominant dropseed, made it more susceptible to injury by fires in the late spring. The centers of the plant bunches were comprised of compact dead tillers that were observed to smolder for an extended period of time after the passage of the fire front. Increased duration of exposure of meristematic tissue to heat probably injured viable tillers and suppressed yields in June and July following late spring burning. Other caespitose species generally respond negatively to late spring burning due to accumulation of litter within the plant crown, and are especially susceptible to fire injury when conditions are dry (Towne and Owensby 1984, Wright 1971).

Weaver (1954) described the dropseeds as highly drought tolerant species commonly found on upland prairie sites. He noted that the quality and palatability of these grasses rapidly declined as summer progressed. We observed that prairie and tall dropseed were not selected by cattle grazing areas adjacent to the research site at Virginia, which suggests that dropseed suppression may be a desirable management objective in grazed tallgrass prairies.

Indiangrass was influenced $(\mathrm{P}=0.05)$ by the combination of spring burning date and atrazine application, but responses to specific treatments were variable. Mid-spring burning combined with atrazine reduced indiangrass accumulated standing crop (ASC) in August by 79\% compared to mid-spring burning with no atrazine (Table 3). Late spring burning combined with atrazine increased indiangrass ASC in August by nearly 9-fold compared to late spring burning with no atrazine.

Accumulated standing crop (ASC) of other warm-season grasses was influenced $(P=0.01)$ by spring date in 1989 and 1990 . Other warm-season grass ASC in August 1989 was increased by

Table 3. Indiangrass accumulated standing crop in June, July, and August following spring applications of fire and atrazine to tallgrass prairies near Lincoln and Virginia, Nebr, in 1989 and 1990.

\begin{tabular}{lcccc}
\hline \hline \multirow{2}{*}{$\begin{array}{l}\text { Spring } \\
\text { burning }\end{array}$} & Atrazine & June & July & August \\
\cline { 2 - 5 } None & $\left(\mathrm{kg} \mathrm{a.i.} \mathrm{ha}{ }^{-1}\right)$ & $\cdots \cdots$ & $\left(\mathrm{kg} \mathrm{ha}^{-1}\right)$ & $\cdots$ \\
& 0 & 200 & 330 & 160 \\
Early & 2.2 & 280 & 440 & 180 \\
& 0 & 340 & 430 & 380 \\
Mid & 2.2 & 430 & 430 & 270 \\
& 0 & 400 & 200 & 710 \\
Late & 2.2 & 570 & 340 & 150 \\
& 0 & 210 & 630 & 60 \\
& 2.2 & 260 & 340 & 520 \\
& LSD $_{(0.05)}$ & & 430 & \\
\hline
\end{tabular}

${ }^{1}$ Averaged across sites, years, and fertilizer treatments. 
burning in mid- and late spring (Fig. 2c). Drought conditions that persisted in 1989 may have caused increased senescence that resulted in negative ASC in August on areas not burned and areas burned in early spring. Burning in late spring 1990 increased the July ASC of other warm-season grasses to $490 \mathrm{~kg} \mathrm{ha}^{-1}$ when compared to not burning or burning in mid-spring.

\section{Cool-Season Grasses and Sedges}

The small contribution $(\leq 3 \%)$ of cool-season grasses to standing crop at Lincoln reduced our ability to discern treatment effects at that site (Table 1). Evaluation of treatment effects on this group of species was limited to the site at Virginia where cool-season grasses averaged at least $16 \%$ of the total plant herbage (Table 1). Burning in late spring reduced $(\mathrm{P}<0.01)$ coolseason grass ASC in June by $86 \%$ when compared to non-burned areas (Fig. 3a). This reduction could have resulted from removal of the top growth of the cool-season grasses and damage to the

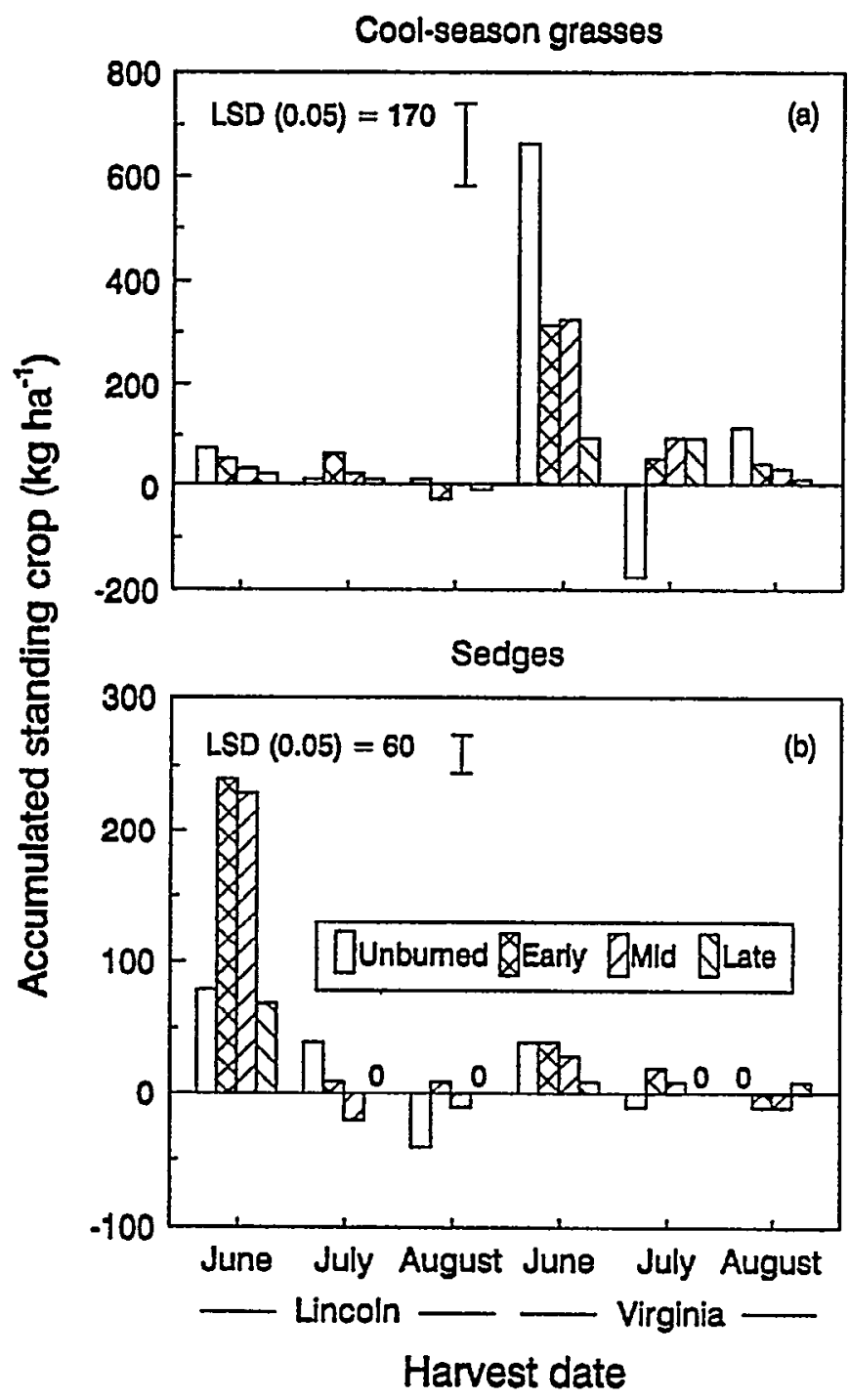

Fig 3. Accumulated standing crop of (a) cool-season grasses and (b) sedges harvested in June, July, and August following spring burning on 3 dates at tallgrass prairies near Lincoln and Virginia, Nebr. in 1989 and 1990. Values are averaged across years and fertilizer and atrazine treatments. meristematic tissue at a time that usually coincides with peak production of cool-season grasses (Waller et al. 1986). Cool-season grass accumulated standing crop (ASC) was not affected by fertilization $(\mathrm{P}=0.11)$ or atrazine application $(\mathrm{P}=0.11)$.

Accumulated standing crop (ASC) of sedge species was greater at Lincoln than at Virginia, although sedges were a minor component at both sites (Table 1). Sedge ASC was affected $(\mathrm{P}<0.01)$ by early and mid-spring burning only in June at Lincoln (Fig. 3b), but was not affected by fertilization ( $\mathrm{P}=0.59)$ or atrazine application $(\mathrm{P}=0.12)$. Burning in early or mid-spring increased sedge ASC in June by at least $187 \%$ compared to areas not burned and areas burned in late spring, but had no influence on ASC in July or August. Sedge ASC on areas that were not burned or burned in late spring was reduced at least $65 \%$ when compared to areas burned in early and mid-spring. Reduced sedge ASC in the areas not burned probably resulted from attenuation of light caused by litter accumulation. Burning in early or mid-spring removed litter before sedge shoot apices were elevated and susceptible to damage by the fire. Fire-induced litter removal opened up the canopy, which improved the light environment and sedge production. Knapp and Seastedt (1986) indicated that the massive amounts of plant litter that can accumulate in tallgrass prairies reduce the quantity and quality of light reaching emerging plant shoots. Reduced sedge ASC following late spring burning may have occurred because the apical meristems were elevated and consumed by the fire. Reduced ASC in July and August reflected the increased maturity and senescence of the cool-season sedges.

\section{Forbs}

Sampling methods used in this study apparently were not sufficiently sensitive to accurately assess the impact of the various treatments on the forb component of the prairie communities. The history of application of the broadleaf-specific herbicides, 2,4-D and dicamba, to control musk thistle at or near the sites at Virginia and Lincoln probably reduced forb abundance and richness.

\section{Conclusions}

Date of spring burning influenced the quantity and distribution of tallgrass prairie vegetation production during the summer more than fertilizer or atrazine. Burning in late spring increased big bluestem accumulated standing crop later in the growing season and decreased cool-season grasses, prairie dropseed and tall dropseed. Fertilization increased the quantity of big bluestem, but vegetation response to fertilizer was more variable than response to burning date. Atrazine had negligible or variable effects on tallgrass prairie vegetation. Atrazine does not appear to be a useful tool to improve warm-season grass forage production in late seral tallgrass prairies. This is fortunate since atrazine is no longer registered for use on rangeland or pastures.

This study provides evidence that the quantity of big bluestem available during the summer can be manipulated by burning on different dates in the spring. Increasing the quantity of big bluestem present in late summer could have a positive effect on performance of livestock grazing tallgrass prairies dominated by big bluestem and alleviate seasonal forage imbalances common to the central Great Plains. A possible management scenario could be to burn tallgrass prairie pastures at different dates during 
the spring. We suggest that a firm could burn some pastures in early spring to increase late spring forage availability, bum other pastures in mid-spring to increase mid-summer forage availability, and burn the remaining pastures in late spring to improve forage availability in mid- to late summer.

\section{Literature Cited}

Anderson, K.L. 1965. Time of burning as it affects soil moisture in an ordinary upland bluestem prairie in the Flint Hills. J. Range Manage. 18:311-316.

Engle, D.M., T.G. Bidwell, J.F. Stritzke, and D. Rollins. 1990. Atrazine and buming in tallgrass prairie infested with prairie threeawn. J. Range Manage. 43:424-427.

Engle, D.M., J.F. Stritzke, T.G. Bidwell, and P.L. Claypool. 1993. Late-summer fire and follow-up herbicide treatments in tallgrass prairie. J. Range Manage. 46:542-547.

Gillen, R.L., D. Rollins, and J.F. Stritzke. 1987. Atrazine, spring burning, and nitrogen for improvement of tallgrass prairie. J. Range Manage. 40:444-447.

Graves, J.E. and W.E. McMurphy. 1969. Burning and fertilization for range improvement in central Oklahoma. J. Range Manage. 22:165-168.

Knapp, A.K. 1985. Effect of fire and drought on the ecophysiology of Andropogon gerardii and Panicum virgatum in a tallgrass prairie. Ecol. 66:1309-1320.

Knapp, A.K., and T.R. Seastedt. 1986. Detritus accumulation limits productivity of tallgrass prairie. BioScience 36:662-668.

Krueger, C.R. and D.C. Curtis. 1979. Evaluation of big bluestem, indiangrass, sideoats grama, and switchgrass pastures with yearling steers. Agron. J. 71:480-482.

Kucera, C.L. and J.H. Ehrenreich. 1962. Some effects of annual burning on central Missouri prairie. Ecol. 43:334-336.

Masters, R.A., K.P. Vogel, and R.B. Mitchell. 1992. Response of central plains tallgrass prairies to fire, fertilizer, and atrazine. J. Range Manage. 45:291-295.

Mitchell, R.B., R.A. Masters, S.S. Waller, K.J. Moore, and L.E. Moser. 1994. Big bluestem production and forage quality responses to burning date and fertilizer in tallgrass prairies. J. Prod. Agr. 7:355-359.

Moore, K.J., L.E. Moser, K.P. Vogel, S.S. Waller, B.E. Johnson, and J.F. Pedersen. 1991. Describing and quantifying growth stages of perennial forage grasses. Agron. J. 83:1073-1077.

Moser, L.E. and K.L. Anderson. 1965. Nitrogen and phosphorous fertilization of bluestem range. Trans. Kansas Acad. Sci. 67:613-616.

Old, S.M. 1969. Microclimate, fire and plant production in an Illinois prairie. Ecol. Mongr. 39:355-384.

Owensby, C.E. and E.F. Smith. 1979. Fertilizing and burning Flint Hills bluestem. J. Range Manage. 32:254-258.

Peet, M., R. Anderson, and MI.S. Adams. 1975. Effect of fire on big bluestem production. Amer. Midl. Nat. 94:15-26.

Rehm, G.W., R.C. Sorensen, and W.J. Moline. 1976. Time and rate of fertilizer application for seeded warm-season and bluegrass pastures. I. Yield and botanical composition. Agron. J. 68:759-764.

Samson, J.F. and L.E. Moser. 1982. Sod-seeding perennial grasses into eastern Nebraska pastures. Agron. J. 74:1055-1060.

SAS. 1985. SAS users guide; statistics. SAS Inst., Inc., Gary, N.C.

Steel, R.G.D. and J.H. Torrie. 1980. Principles and procedures of statistics: a biometrical approach, 2nd ed. McGraw-Hill Book Co., N.Y.

Svejcar, T.J. 1990. Response of Andropogon gerardii to fire in the tallgrass prairie. p. 19-27. In: S.L. Collins and L.L. Wallace (eds.), Fire in North American tallgrass prairies. University of Oklahoma Press, Norman Olila.

Svejcar, T.J. and J.A. Browning. 1988. Growth and gas exchange of Andropogon gerardii as influenced by burning. J. Range Manage. 41:239-244.
Towne, G., and C.E. Owensby. 1984. Long-term effects of annual burning at different dates in ungrazed Kansas tallgrass prairie. J. Range Manage. 37:392-397.

Waller, S.S., L.E. Moser, and B. Anderson. 1986. A guide for planning and analyzing a year-round forage program. Nebraska Coop. Ext. Serv. EC 86-113-C.

Waller, S.S. and D.K. Schmidt. 1983. Improvement of eastern Nebraska tallgrass range using atrazine and glyphosate. J. Range Manage. 36:87-90.

Weaver, J.E. 1954. North American Prairie. Johnsen Publ. Co. Lincoln, Nebr.

Wright, H.A. 1971. Why squirreltail is more tolerant to burning than needle-and-thread. J. Range Manage. 24:277-284. 